\title{
RESEARCH ON WEBSITES OF 43 PUBLIC RELATIONS AGENCY MEMBERS OF PUBLIC RELATIONS SOCIETY OF TURKEY (TÜHID) IN ASPECT OF PUBLIC RELATIONS
}

\author{
Ş.Güzin Ilıcak AYDINALP \\ Istanbul Kültür University, Faculty of Arts and Design, Turkey \\ g.ilicak@iku.edu.tr
}

\begin{abstract}
Nowadays public relations studies have entered a more effective process via recent media tools. In this study, the websites of 43 public relations agency members of Public Relations Society of Turkey (TÜHID) are being evaluated in aspect of public relations. When considered from this point of view, the websites of the agencies in question have been analyzed in terms of company information, communication attempts, media relations, corporate identity, corporate publications and interaction. The study has been designed using content analysis method of qualitative research methodology to research the websites of aforesaid 43 public relations agencies. Since the websites of 12 agencies are under construction, the rest 31 websites have been taken under review. The data obtained from this study has revealed to what extent the websites of public relations agencies are being appropriately and effectively used in terms of public relations techniques.
\end{abstract}

Keywords: Websites, Public Relations Agency, TÜHİD, Public Relations Techniques

\section{INTRODUCTION}

Recent communication technologies and the transformation of these technologies on communication models provide public relations discipline feeding on communication field with new opportunities. Public relations specialists need to track the revolving and advancing technologies closely (Pohl\&Vandeventer, 2001, p.367). Within this period, especially the websites are the key points of corporations in that they express themselves to the target audience. Because any sort of information can be instantly gained with an independency of time and space through websites. According to Auger, the increase in the number of websites makes it difficult for corporates to drive the traffic to their websites. Next aim following the attention to website is how to present an attractive and rich in content website to the audience (Haas, 2002, p.637). Piccoli and others state that the websites of companies are gradually becoming a component of consumer services. It is important to be decisive in design and functionality of the websites, since they have a direct influence on consumer's decision. Econsumers want instant, user-friendly and high quality of supplier websites (Zhao \& Gutierrez, 2001, p.18). Therefore, public relations specialists shoulder a great responsibility of conducting the design and functionality of the websites. The websites used for information multiplying and teleconference system by public relations specialists are important. Websites save the public relations specialists from such former expenses as post, photocopy etc. while spreading the knowledge. These pages can also be accessed at any time all the year round. The e-mail access on these pages enables to detect the impression of visitors on corporation, brand or services. While designing the websites, the public relations specialist must answer all the questions regarding which receptors can have an access to websites, whether the websites can be used to enable the increasing interaction, who will be the webmaster responsible for maintaining and updating the website, how the website will be integrated with the message distribution system (Lordan, 2001, p.587). This is because all the information about the corporation can be obtained via these pages. A public relations specialist must manage his/her website accordingly. He/she must run the website accomplishedly in flow of information, crisis management and company profile. The information must be up-to-date and active. 


\section{LITERATURE}

\section{Public Relations Agencies in Turkey}

Public relations activities feeding on different branches of science are as old as the human history itself is. When the Turkish history is reviewed, the very first examples of these studies in field go back to Orkhon Inscriptions of Gokturks. Later in the Seljuk Empire period, Nizam-ül Mülk mentioned the necessity of informing the reign about the opinion, thought, estimation and wishes of the public in his work called "Siyasetname". The emperors of the Anatolian Seljuk Empire spared some to time to listen to the problems of public (Onal, 1997, p.6). As a result, it is clearly seen that public relations activities were gropely proceeded, which is different from today's. In a modern sense, public relations activities began with the establishment of Anadolu Agency and releasing the reforms to the public by Atatürk in Turkey. Such departments as publicity office, public information agency, information office and media advisory which are responsible for public relations in public enterprises were subsequently established. The literal practice of public relations dates back to late 1960s. General Directorate of Press and Information of Foreign Ministry and Directorate of Press and Information of Ministry of Defense are the examples relevant to public relations (Geçikli, 2008, p.12). Afterwards agencies were established to realize all the activities of public relations.

A\&B Public Relations Company was founded by Alaeddin Asna in 1974 as the first PR company in Turkey (Geçikli, 2008, p.14). A\&B Public Relations Company rendered a service during 10 years as the only communication consultancy company in the sector (Peltekoğlu, 2004, p.101). During the foundation of A\&B, Alaeddin Asna stated that he worked as a "missionary" for this business and regarded Turkey as equal to other countries worldwide. Asna also stated that he felt intensely frightened whether the company would succeed or not in the very early years following the foundation, but in the course of time, he conqured all his fear after conducting successful business (Peltekoğlu\&Saydam, 2008, p.11-12). The very aim of the foundation of PR agencies is to render consultancy services to the companies. Since the agencies give outside support to the corporations, their supervision skills developed. The agencies can easily distinguish the pluses and minuses of corporations. The agencies are rich in educated and well-equipped people. They also have more financial and technical opportunities than the intra-agency PR unit has. Being a close follower of the sector, they are always in a pursuit of innovations. The biggest disadvantage of the agencies is that they have inadequate knowledge on intra-agency. They might be late and limited in the event of a crisis in the field of communication. Sometimes they might have problems while getting paid by corporations. They might not be well-equipped and well-informed on the field that the corporation works. Ceyda Aydede, being the former president of IPRA and the founder of Global Tanıtım Halkla İlişkiler, proposes that the agencies in Turkey can succeed through sustainability, and this can only realize through institutionalization of the agencies (Peltekoğlu \& Saydam, 2008, p.67-68). When compared to PR activities across the world, it can be said that PR consultancy agencies working universally and contemporaneously in Turkey become gradually successful. As a reason, the international awards received and world presidencies can be good examples. The emergence of new agencies is a progress. Foreign capital is also invested in the agencies in Turkey. Trade bodies in the field gain strength. Educated and specialized individuals have started working in the agencies. The main problems which can be encountered in the agencies as follows: Consultancy fees do not reach the foreign level. There can be occasional problems about investment and adequate employment. There can be some trouble on convincing the clients about research and measurement. There can be difficulty arising from the different interpretation of code of ethics between agencies. The leading motivation of the foundation of Public Relations Society of Turkey (TÜHID) in 1972 is to bring the PR specialists together and the code of ethics to be adopted. The corporation having connections with IPRA or other international corporations has witnessed a gradual increase in the number of its members. "TÜHID Young Communicator Support Grant" is prominent for the students who consider working in this field. 


\section{METHODOLOGY}

\subsection{Method}

The research method is the content analysis being one of the qualitative research methods. Content analysis is a method which can be adopted for different objectives in the fields of political sciences, journalism, PR, psychology, sociology, history, literature, etc.. Symbolic conduct or communication materials are tried to be explained and solved. According to Janis, under the conditions of relying on the judgement of the analyst who is a scientist and depending on the judgement which presents clearly formulized codes of the analyst or analyst group, content analysis is the classification of the communication tools and their adoption to solve problems (Janis In: Holsti, 1968). The study has been conducted by a proper screening model in accord with the purposes. Screening model aims to describe the preexisting condition without changing it (Karasar, 1998, p.77). In this sense, 43 PR agency members of TÜHID were chosen. However, since their websites are under construction, only 31 websites are reviewed according to the scale consisting of 34 criterion prepared by Öztürk and Ayman in 2007.

Table 1: The Criterion of Websites in Aspect of Public Relations

\begin{tabular}{|c|c|c|}
\hline & Category & Operational Definition \\
\hline 1 & Corporate information & $\begin{array}{l}\text { General knowledge on corporate (products, services, } \\
\text { capacity) }\end{array}$ \\
\hline 2 & $\begin{array}{l}\text { Resume of the corporate's } \\
\text { executives }\end{array}$ & Name, education, former workplaces and position \\
\hline 3 & Corporate history & Story of foundation \\
\hline 4 & Corporate field & Products and services \\
\hline 5 & Organization chart & A Chart indicating the operation of organization \\
\hline 6 & Vision & Corporate's point of view \\
\hline 7 & Mission & Corporate's fundamental reason for being \\
\hline 8 & Emblem & $\begin{array}{l}\text { A special design or visual object reflecting the features of } \\
\text { corporate }\end{array}$ \\
\hline 9 & Logo & $\begin{array}{c}\text { A unique character set or graphic design reflecting the name } \\
\text { of corporate }\end{array}$ \\
\hline 10 & Music & $\begin{array}{l}\text { Other than commercial song, a song or corporate march } \\
\text { playing on an introductory basis on website }\end{array}$ \\
\hline 11 & Announcements & The links put by corporate on Announcement \\
\hline 12 & On-line magazine or journal & The links put by corporate on Magazine or Journal \\
\hline 13 & Brochures & The links put by corporate on Brochures \\
\hline 14 & Reports & The links put by corporate on Reports \\
\hline 15 & Corporate presentation video & Movies or animations about corporate \\
\hline 16 & E-book & $\begin{array}{c}\text { E-books relevant to corporate (stories of foundation, } \\
\text { biographies, tales of success) }\end{array}$ \\
\hline 17 & Press Issues & Press Issues published by corporate \\
\hline 18 & Press Archive & $\begin{array}{c}\text { A unit where the news or other issues about corporate and } \\
\text { employees are kept }\end{array}$ \\
\hline 19 & Picture and Photos & Picture and Photos of corporate on a similar title \\
\hline 20 & Activity Calendar & An Activity Calendar indicating the corporate activities \\
\hline 21 & Contact Address & $\begin{array}{c}\text { Contact Address of corporate (e-mail address, phone, fax } \\
\text { number) }\end{array}$ \\
\hline 22 & Printed Advertisement & $\begin{array}{l}\text { Advertisement images or folds that can be unfolded or } \\
\text { loaded }\end{array}$ \\
\hline 23 & Outdoor Ads. & Outdoor Ads. images or folds that can be unfolded or loaded \\
\hline 24 & Radio Ads. & Radio Ads. folds that can be unfolded and loaded \\
\hline 25 & Television Ads. & Television Ads. folds that can be unfolded and loaded \\
\hline 26 & Activities & The links put by corporate on Activities \\
\hline 27 & Seminars and Conferences & The links put by corporate on Seminar ve Conferences \\
\hline 28 & $\begin{array}{c}\text { Exhibitions, Fair and } \\
\text { Competitions }\end{array}$ & $\begin{array}{c}\text { The links put by corporate on Exhibitions, Fair and } \\
\text { Competitions }\end{array}$ \\
\hline
\end{tabular}




\begin{tabular}{|c|c|c|}
\hline 29 & Celebrations & The links put by corporate on Celebrations \\
\hline 30 & Sponsor & The links put by corporate on Sponsor \\
\hline 31 & Social Responsibility & The links put by corporate on Social Responsibility \\
\hline 32 & E-mail & $\begin{array}{c}\text { The presence of e-mail address of corporate or a specific } \\
\text { person }\end{array}$ \\
\hline 33 & Forum & $\begin{array}{c}\text { The presence of a segment on website where the visitors are } \\
\text { able to write their opinions, wishes and complaints }\end{array}$ \\
\hline 34 & News \& Forum & The presence of relevant links \\
\hline
\end{tabular}

The Criterion of Websites in Aspect of Public Relations (Öztürk and Ayman)

Table 2: The Member Agencies of TÜHİD and Their Websites

\begin{tabular}{|c|c|}
\hline THE MEMBER AGENCIES OF TÜHİD & THEIR WEBSITES \\
\hline 1 Image Halkla İlişkiler & http://www.image-pr.net \\
\hline 2 A\&B İletişim A.Ş. & http://www.ab-pr.com/ \\
\hline 3 Arya Sponsorluk & http://www.aryasponsorluk.com.tr/ \\
\hline 4 Bernaylafem & http://www.bernaylafem.com/ \\
\hline 5 Bersay Stratejik İletişim Danışmanlığı & http://www.bersay.com.tr/ \\
\hline 6 Beyaz Sosyal Sorumluluk ve Danışmanlık & http://www.beyazsosyalsorumluluk.com/ \\
\hline 7 BG İletişim ve Halkla İlişkiler & http://www.bgiletisim.com/ \\
\hline 8 Bizce Tanıtım Organizasyon & http://www.bizcetanitim.com/ \\
\hline 9 Communication Partner İletişim Danışmanlığı & http://www.cpartner.com.tr/ \\
\hline 10 Denove Halkla İlişkiler & http://www.denovepr.com/ \\
\hline 11 Departman Medya İletişim Hizmetleri & http://www.departmanmedya.com/ \\
\hline 12 Effect Halkla İlişkiler & $\begin{array}{c}\text { http://www.effect- } \\
\text { pr.com/channels/1.asp?id=45 }\end{array}$ \\
\hline 13 EnPR İletişim & http://www.enpr.com.tr/ \\
\hline 14 Excel İletişim Danışmanlığı & http://www.excel.com.tr \\
\hline 15 Grup7 İletişim Hizmetleri & http://www.grup7.com.tr/ \\
\hline 16 Hisdaş Medyapol & http://www.hisdasmedyapol.com/ \\
\hline 17 İDEA Halkla İlişkiler ve Tanıtım & http://www.idea-pr.com/ \\
\hline 18 Keçi Organizasyon & http://www.kecievents.com/ \\
\hline 19 Leo PR & http://www.leopr-tr.com \\
\hline 20 MESE İletişim Danışmanlığı & http://www.mese.com.tr/ \\
\hline 21 MPR Halkla İlişkiler & http://www.mpr.com.tr \\
\hline 22 Plan PR & http://www.plan-pr.com/ \\
\hline 23 POZİTíF PR & http://www.pozitifpr.com/ \\
\hline 24 PR Aktif İletişim Hizmetleri & http://www.praktif.com.tr \\
\hline 25 PRO İletişim Danışmanlığı & http://www.proiletisim.com/ \\
\hline 26 Promedia Halkla İlişkiler Ltd. Şti. & http://www.promedia.com.tr/ \\
\hline 27 Rekta Reklam Ve Tanıtım Hizmetleri & http://www.rekta.com.tr/main.html \\
\hline 28 Seçil Şendağ Stratejik İletişim Danışmanlığı & http://www.secilsendag.com.tr/ \\
\hline 29 Stage İletişim Danışmanlığı & http://www.stagepr.com/ \\
\hline 30 Toksü ve Chase Halkla İlişkiler & http://www.toksuvechase.com/ \\
\hline 31 Zarakol İletişim Hizmetleri & http://www.zarakol.com.tr/ \\
\hline 32 Assist İletişim Danışmanlığı & Under Construction \\
\hline 33 Beze Group & Under Construction \\
\hline 34 BPR Halkla İlişkiler & Under Construction \\
\hline 35 Cohn\&Wolfe Türkiye & Under Construction \\
\hline 36 Depar Tanıtım & Under Construction \\
\hline 37 Global Tanıtım Halkla İlişkiler & Under Construction \\
\hline $\begin{array}{l}38 \text { İMAGO Reklam Ajans Organizasyon } \\
\text { Hizmetleri A.Ş. }\end{array}$ & Under Construction \\
\hline 39 M3 Halkla İlişkiler & Under Construction \\
\hline 40 Medialand Halkla İlişkiler & Under Construction \\
\hline 41 Ogilvy\&Mather Türkiye & Under Construction \\
\hline 42 On İletişim & Under Construction \\
\hline 43 MS REKLAM HİZMETLERİ A.Ş. & Under Construction \\
\hline
\end{tabular}




\subsection{Research Objectives}

The survey research objective is to detect how the PR agencies use PR techniques on their websites. How the agencies supporting various corporations in terms of PR on their websites use these techniques on their own websites will be disclosed. And thus suggestions are expected to be offered regarding the possible shortages.

\subsection{Importance of the Research}

PR agencies have to use internet efficiently, especially their own website in order to carry on the activities. Websites provide people instantly and easily with any sort of information and image about the corporations. Therefore, the agencies rendering PR services need to design their own PR on their websites. This study is important to see if member agencies of TÜHIDD design the PR on their websites appropriately or not.

\subsection{Scopes and Limitations of Research}

The scope of the research is formed by the member agencies of Public Relations Society of Turkey (TÜHID). The limit of the research is the time period when the websites are analyzed (15 November - 15 December 2011). Since the study reveals the activities of a specific period, there might have been changes on the websites following the assessments. Due to the dynamic mechanism of websites, possible changes of data obtained from the studies conducted at different times may be tracked down.

\subsection{Universe and Sample}

The universe of the study is all the agencies working on PR in Turkey. However, due to the lack of knowledge on the number of PR agencies, only 43 member agencies being on the TÜHID's offical website were not taken into consideration. On the date of the study (15 November - 15 December 2011), the websites under construction or ghost sites (12) were exluded from the study. It was confirmed by phone calls with the authorized person that their websites were under construction or no longer in service. The rest 31 websites in service were analyzed by online visiting.

\subsection{Data Collection}

PR agencies applied to the screening model of qualitative research methods during data collection. A different assessment form was used for each visited website, the websites were individually analyzed according to the 34 criterion, and each one was visited only once due to their dynamic construction. Following the visits, the data was saved in the assessment form. The assessment of criterion under each category in the assessment forms was marked as present (1) and absent (0). The data, along with the researcher, was gathered with the help of an instructor knowledgeable with content analysis. Two researchers coded in this study. In order to provide the security during coding, Krippendorff's approach (1980) which seeks the way of connecting two or more coders on the codes was adopted. The consistency between the codes was recorded as $96 \%$.

\subsection{Analysis of Data}

The websites of $31 \mathrm{PR}$ agencies in the scope of sampling were aimed to be analyzed according to the 34 criterion. The points of each criteria was added and the overall tendency of each criteria was estimated. While the criterion are listed at the vertical zone on chart, total points of criterion are listed at the horizontal zone. Moreover, since the agencies were analyzed in terms of using of PR techniques on their websites, the websites of these agencies in question were analyzed with regards to the corporate information, communication studies, media affairs, corporate identity, corporate publications and interaction.

\section{FINDINGS AND INTERPRETATION}

In the scope of this study, the potential of the websites on PR was primarily discussed. Ignoring the web design features, only a public relations-featured analysis was applied. The 
websites of the agencies were analyzed in terms of corporate information, communication attempts, media affairs, corporate identity, corporate publications and interaction. Only 31 agencies out of 43 are in service. Since 12 websites were under construction, they were not taken into consideration.

Table 3: Distribution of Corporate Information

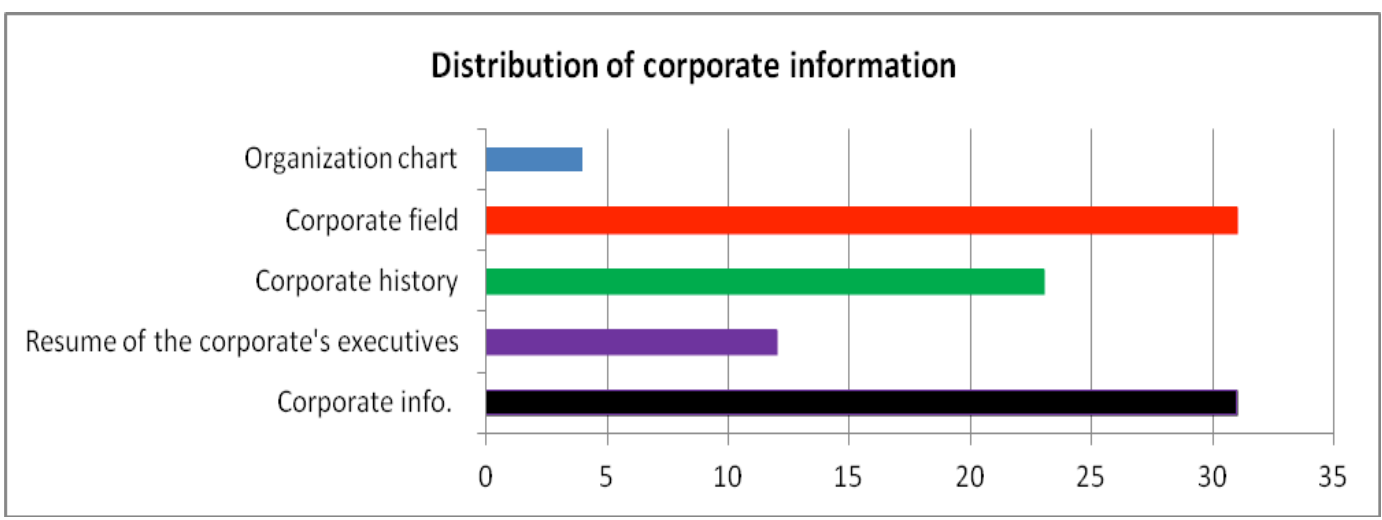

It is seen that the agencies include corporate information on their websites. Five variables aimingly organized to see how the corporate information is supplied to the websites were analyzed. Especially the segments of corporate information and corporate field are located in all 31 agencies. Corporate history is located in 23 agencies. Resume of the corporate's executives is rarely common among the agencies. It is located only in 12 agencies. Organization chart is located in only 4 agencies out of 31 (Table 3 ).

Table 4: Distribution of Information about Corporate Identity

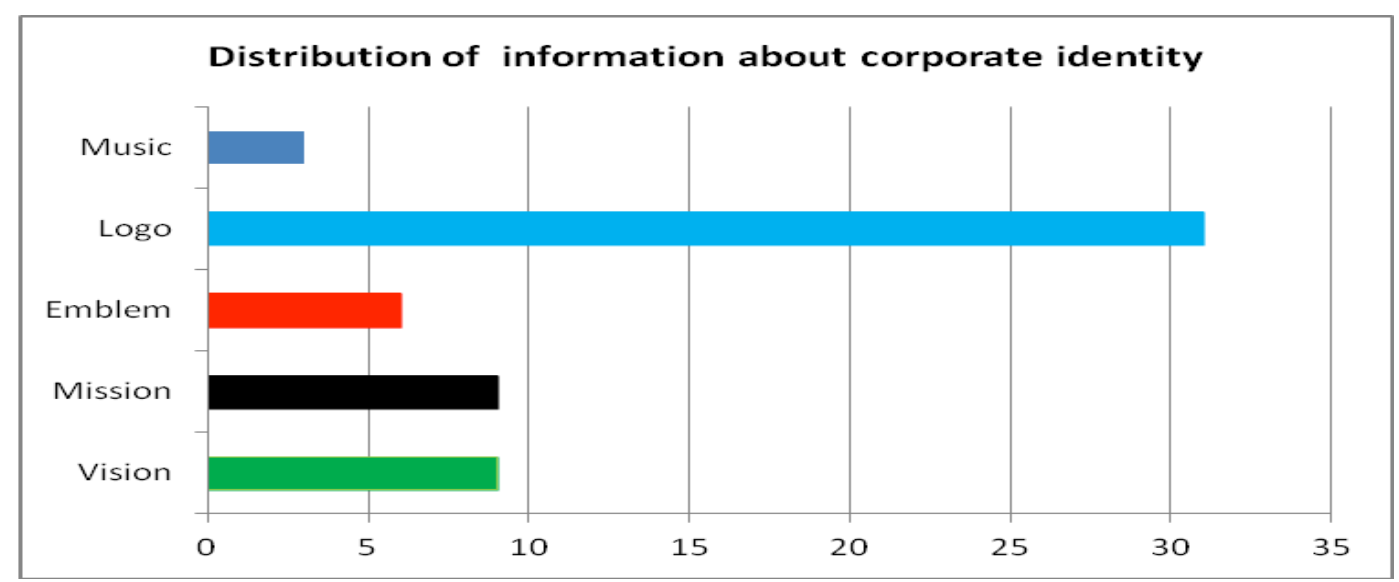

Corporate identity is of importance among the PR applications. The following data obtained when the websites are analyzed in terms of constituent features reflecting the corporate identity: All 31 agencies used a logo on their websites. While mission and vision are located on the websites of 9 agencies, the rest 22 agencies do not have. The emblem and music applications used to introduce the corporate identity are relatively low level (Table 4). 
Table 5: Distribution of Corporate Publications

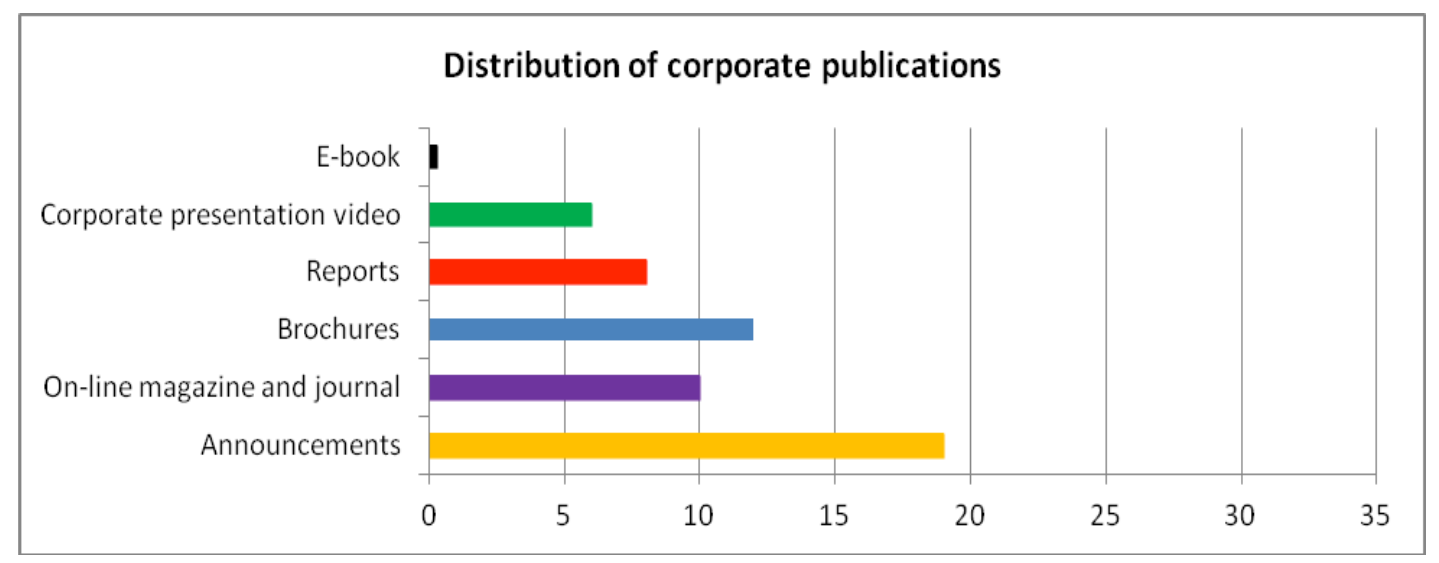

The publications aiming to inform and impress the target audience through the websites of analyzed corporations were encountered. 19 agencies include announcements. 12 agencies include on-line brochures, 10 agencies include on-line magazine and journal and 8 agencies include reports on their websites. 25 agencies do not include corporate presentation video on their websites and almost none of these agencies have e-book application (Table 5).

Table 6: Distribution of Media Relationships

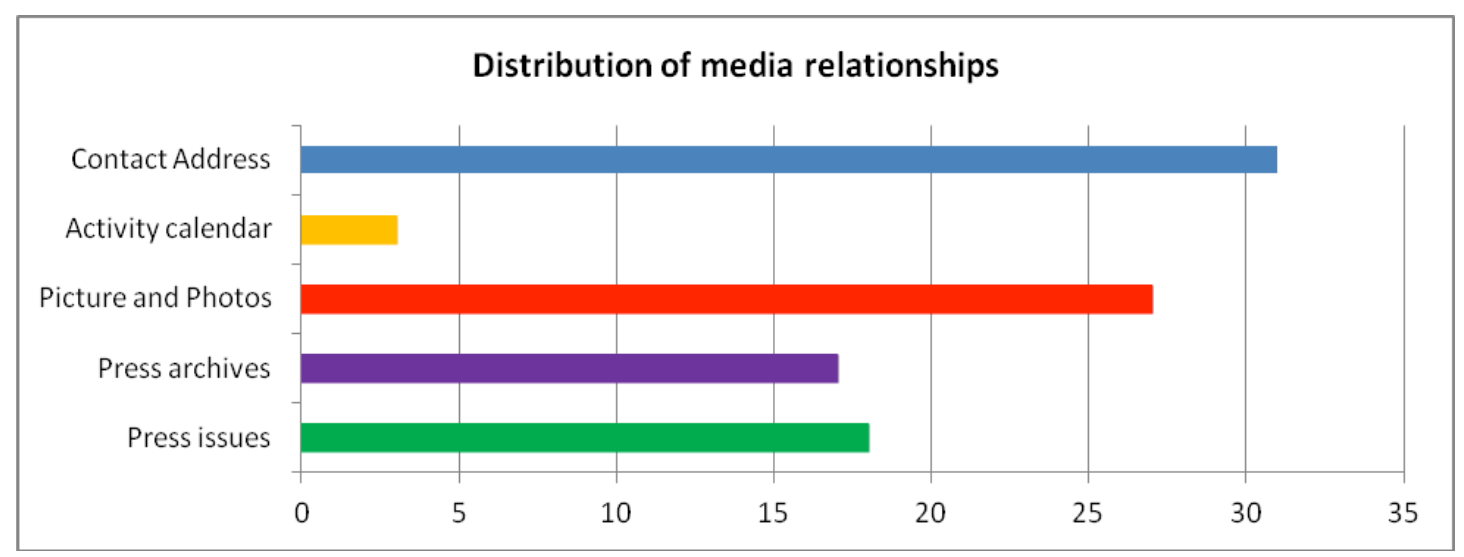

When we analyzed the studies by corporations conducted to make media employee's work easier, these results are obtained: Contact Address of corporate (e-mail address, phone, fax number) is located on the websites of all 31 agencies. 18 agencies include press archive, 17 agencies include press issues. Picture and photos usage are fairly common on websites in PR techniques. 27 agencies have picture and photos application. Only 3 agencies out of 31 have activity calendar (Table 6). 
Table 7: Distribution of Communication Attempts

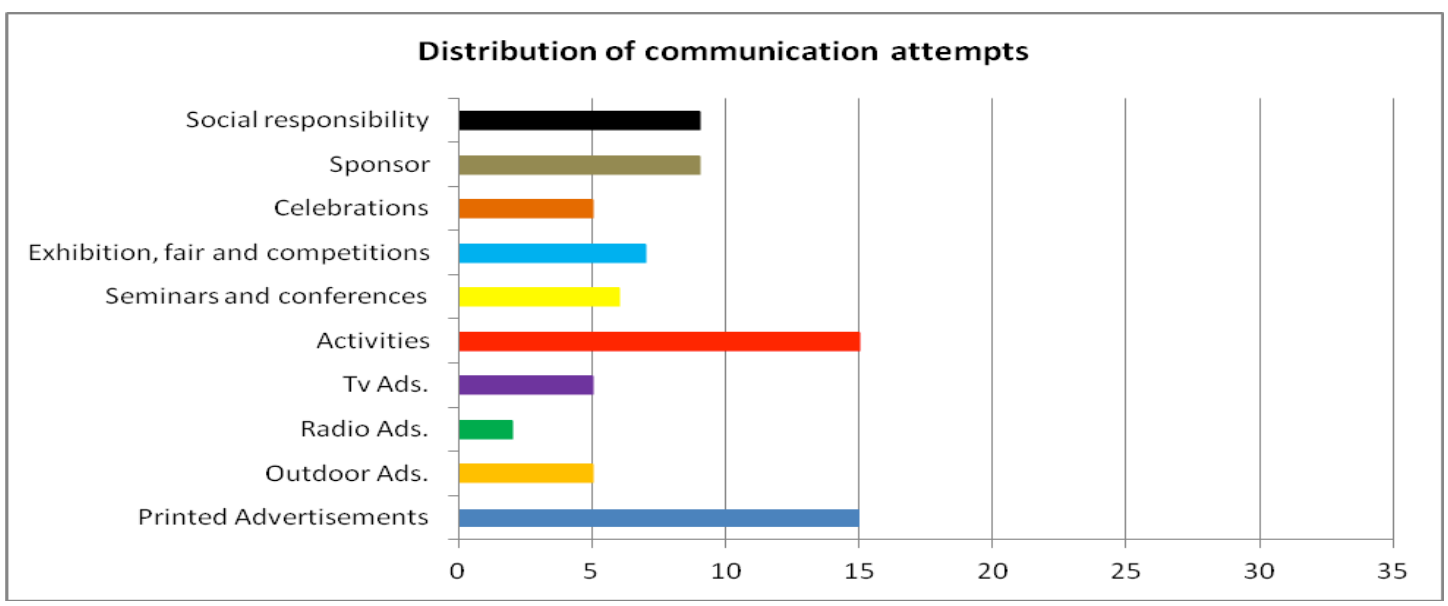

When the agencies were analyzed in to what extent they keep the ads or communication attempts they used on other communication tools, these results are obtained: 15 agencies out of 31 have printed ads. and activities. 9 agencies have sponsor and social responsibility on their websites. 6 agencies have seminar and conferences, 7 agencies have exhibitions, fair and competitions on their websites. Only 5 agencies have outdoor ads., television ads. and celebrations. Almost none of the agencies include radio ads. in PR. Only 2 agencies have radio ads on their websites.

Table 8: Distribution of Communication Attempts through Internet

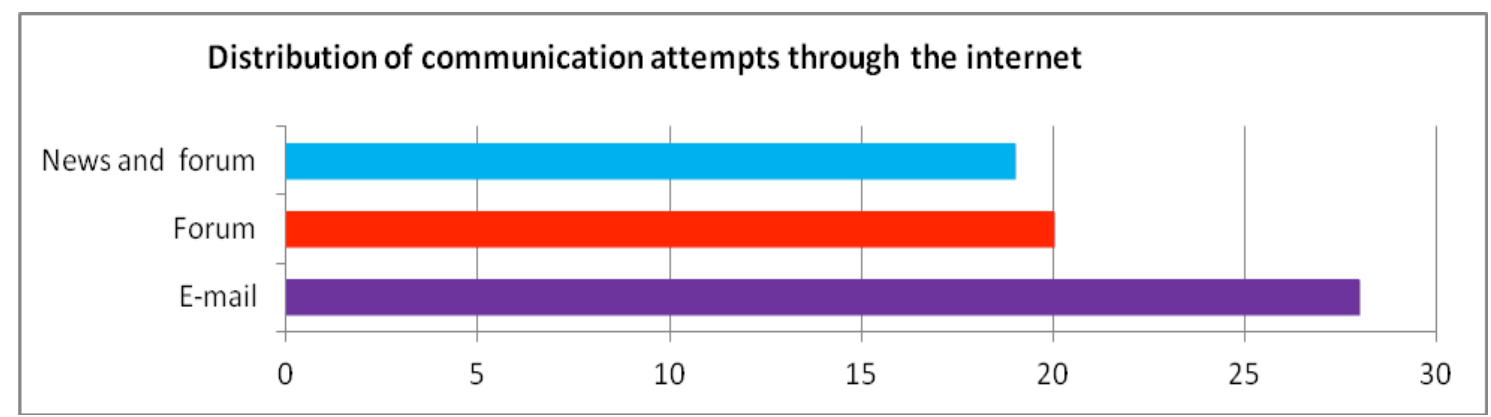

E-mail, forum and news are of importance in the PR activities taking place on websites. 28 agencies out of 31 have e-mail address, but 3 agencies do not have any information about email address. While 19 agencies have news and forum on their websites, 20 agencies do not include forum (Table 8).

Table 9: Usage Rate of PR Techniques on Websites of Member Agencies of TÜHID

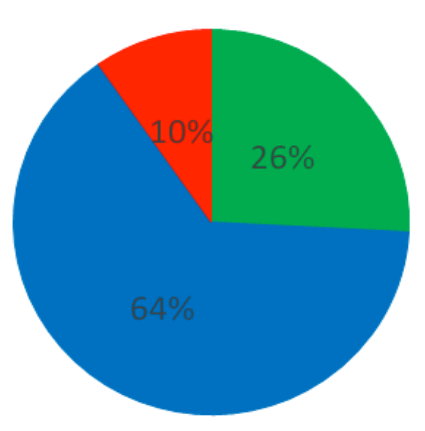

Inefficient Usage

Medium-efficient Usage

Efficient Usage 
Usage rate of PR techniques on websites of member agencies of TÜHID has unrevealed suprising results. While $10 \%$ of 31 agencies use efficiently, $26 \%$ uses inefficiently. $64 \%$ of agencies use medium-efficiently (Table 9).

\section{RESULT AND SUGGESTIONS}

It stimulates interest that how these agencies that support the corporates in PR, and design their PR websites could be inefficient in designing their own websites. Because only $10 \%$ of 31 agencies used the websites efficiently in terms of corporate information, communication attempts, media affairs, corporate identity, corporate publications and interaction. The fact that 12 agencies were not even taken into consideration makes one think. Because during the dates of study, 12 agencies could not succeed completing an up-date website to the clients. The agency owners claiming that their websites were under construction did not use their websites. The fact that $64 \%$ of 31 agencies use medium-efficiently is a matter of debate. The reason for that the PR agencies whose job definition is to sustain PR do not work insufficiently enough on their corporate websites. It is essential for PR agencies to include knowledge on their corporates. Thus becomes the target audience knowledgeable with the corporate. It is a positive approach for all the agencies to render information about "corporate" and "corporate fields" at the end of the analysis. However, the agencies need to share "resume of the corporate's executives" and "organization chart" in a more active way. It is emerged that 31 agencies have the awareness on "corporate identity". All the agencies had at least their corporate "logo" on their websites. However, it is fairly weird that the agencies helping the corporates on "mission" and "vision" do not have these values on their websites. Because the results of such criterion as "mission" and "vision" are below the average. Introductive "signature tune" or "emblem" is hardly used. This uncovers the fact that the agencies have to give more importance reflecting their corporate identity on their websites. It is understood that the agencies use intensely their websites to share "announcements" about the corporate, but other broadcast media tools are not often applied. "On-line magazines, journals and brochures" are relatively high in number, while number of "reports" and "corporate presentation video" are notably rare. This result indicates that the agencies were not able to move the traditional studies such as the publication of journals, magazines and books to an on-line level yet. The relationship between PR agencies and media is valuable. In an internet age, the agencies need to move this relationship to their websites. It is clearly seen that the member agencies of TÜHID have tried to put "contact address", "picture and photos", "press archive" and "press releases" information on their websites. However, it is doubtful that they have not shared their "activity calendar" on-line. The agencies can easily put and keep the elements of other communication tools on their websites. They can use the communication tools free on their websites. By this means, they can sustain a close and longterm relationship with public. The agencies use "printed ads." and "activities" on their websites. It is also analyzed that they have "sponsor" and "social responsibility projects" on their websites. But the number of "outdoor ads.", "radio ads.", "television ads.", "exhibitions, fair, competitions" and "celebrations" are relatively rare, which needs attention. This only indicates that the agencies do not value the communication attempts. The agencies had a high level of performance on communication attempts via internet. They try to use their websites interactively. In the lights of these results, for a better and efficient usage, these can be suggested to the PR agencies:

- It would be of great help for all the agencies to add their resume of corporate executive's and organization chart information to their websites to introduce their corporates to the target audience.

- The PR agencies can share the corporate identity they possess more efficiently on their websites. They can compose their signature tune and introduce it to the target audience. 
- It would be better to increase the number of on-line "magazine, journal and brochures" on their websites.

- The agencies should try harder to render the activity reports to the target audience and put their link of "corporate presentation video" on the website.

- The books telling the stories of foundation and tales of success should be transferred into "e-book" application so that many people can reach them on the website.

- The agencies can actively move the ads. they used for their own sake on various channels to their websites.

- The number of the seminars, conferences, exhibitions, fairs, competitions, celebrations and activity calendar can be increased on the website.

\section{REFERENCES}

Fraser, P. (1989). The Practice of Public Relations. Fourth Edition.Ohio:Merrill Publishing Company, Columbus.

Geçikli, F. (2008). Halkla İlişkiler ve İletişim. First Publication. Istanbul: Beta Publishing. Haas, R. (2002). 'The Austrian Country Market: A European Case Study on Marketing Regional Products and Services in a Cyber Mall'. Journal of Business Research 55(8): 637 464.

Holsti, O. (1968). 'Content Analysis', In: G. Lindzey., E. Aronson (Eds.), The Handbook of Social Psychology. London: Addison-Wesley Publishing Company, Inc., vol 2: 596-692.

Karasar, N. (1998). Bilimsel Araştırma Yöntemi. Ankara: Noble Publishing and Distribution.

Lordan, E. (2001). 'Cyberspin, The Use of New Technologies in Public Relations', In: Heath. R., Vasquez, G. (Eds.), Handbook of Public Relations. USA: Sage Publications, 583-589.

Onal, G. (1997). Halkla İlişkiler. Istanbul: Türkmen Publishing House.

Öztürk, M., Ayman M.(2007). 'Web Sayfalarının Halkla İlişkiler Amaçlı Kullanımı', Selçuk University, Faculty of Communication Journal Academic Magazine. Konya: Selçuk Communication Publishing (57-66).

Peltekoğlu, F., Saydam, A. (2008). Sektörün Penceresinden Halkla İlişkiler. First Publication. Istanbul: Bamm Publishing.

Peltekoğlu, F. (2004). Halkla İlişkiler Nedir?. Third Publication. Istanbul: Beta Publishing.

Pohl, G. M., Vandeventer, D. (2001). 'The Workplace, Undergraduate Education and Career Preparation', In: Heath. R., Vasquez, G. (Eds.), Handbook of Public Relations. USA: Sage Publications, 357-368.

Simon, J. L. (1969). Basic Research Methods in Social Science: The Art of Empirical Investigation, Random House. New York.

Zhao, Z., Gutierrez, J. (2001). 'The Fundamental Perspectives in E-Commerce'. In: Singh, M., Teo, T. (Eds.). E-Commerce Diffusion: Strategies and Challenges. Heidelberg Pres, Melborne, 18.

http://www.tuhid.org 